Rok XVI (2021) | 2 (32) | S. 203-213

https://doi.org/10.12797/LV.16.2021.32.16

Anna Tyrpa (1)

Instytut Języka Polskiego Polskiej Akademii Nauk, Kraków

anna.tyrpa@ijp.pan.pl

\title{
KRYSTYNA PISARKOWA - TA, KTÓRA INSPIRUJE
}

Słowa klucze: etnolingwistyka, konotacja semantyczna nazw narodowości, stereotypy etniczne, frazeologia somatyczna, metoda ankietowa

Keywords: ethnolinguistics, semantic connotation of nationalities, ethnic stereotypes, somatic phraseology, survey method

Mój tekst składa się z trzech części. W pierwszej będzie mowa o prof. Krystynie Pisarkowej w roli opiekuna naukowego. W drugiej prześledzę inspirującą rolę jednego Jej artykułu w twórczości czternaściorga uczonych. Trzecia część nosi tytuł Suplement, bo rzeczywiście jest suplementem, a nadto o pewnym suplemencie traktuje.

\section{Krystyna Pisarkowa jako promotor}

Prof. K. Pisarkowa wypromowała sześcioro doktorów ${ }^{1}$. Oto ich lista:

- 1971: Jadwiga Konieczna-Twardzikowa, Zdania rozwijajace w polskim systemie opozycji hipotaktycznych;

- 1980: Anna Kałkowska, Struktura składniowa listu;

- 1982: Barbara Greszczuk, Konstrukcje porównawcze i ich rozwój w języku polskim;

- 1985: Anna Krawczyk, Frazeologia somatyczna w gwarach polskich. Związki frazeologiczne o znaczeniach motywowanych cechami części ciała;

1 Podaję za: Karpluk 2010: 162 i Kowalik 2010: 9. 
- 1993: Tadeusz Szczerbowski, O grach językowych w tekstach polskiego i rosyjskiego kabaretu lat osiemdziesiątych;

- 2001: Magdalena Ruta, Dwujęzyczna twórczość literacka. Przypadek Kalmana Segala.

W dalszym ciągu tekstu pragnę podzielić się własnymi refleksjami na temat prof. Pisarkowej w roli opiekuna naukowego. Żeby powiedzieć, jakim promotorem była, muszę najpierw wyjaśnić, jak doszło do tego, że zgodziła się wziąć mnie pod swoje skrzydła. Pracę magisterską napisałam pod kierunkiem prof. Mieczysława Karasia, który stał się moim przełożonym najpierw w Instytucie Filologii Polskiej UJ, a potem w Instytucie Języka Polskiego Polskiej Akademii Nauk. Było więc oczywiste, że będzie również promotorem mojego doktoratu. Postanowiłam zająć się frazeologią gwarową, korzystając z dostępu do kartoteki Słownika gwar polskich, w którego opracowaniu brałam udział. 10 sierpnia 1977 r. prof. Karaś zakończył życie. W naszym Zakładzie Dialektologii Polskiej IJP PAN nie było wówczas nikogo z habilitacją, kto mógłby opiekować się doktorantką. Zwróciłam się o radę do prof. Romana Laskowskiego. Ten skierował mnie do prof. Andrzeja Marii Lewickiego z Uniwersytetu Marii Curie-Skłodowskiej. Jeździłam regularnie do Lublina na zebrania frazeologiczne, ściągające badaczy z całej Polski. Wreszcie spytałam dyrektora IJP PAN, prof. Stanisława Urbańczyka, czy prof. Lewicki mógłby zostać moim promotorem. Odpowiedź była odmowna ${ }^{2}$. Wtedy pomyślałam o prof. Pisarkowej. Znałam Ją z zebrań naukowych i odczytów, w czasie których prezentowała nowe prądy w językoznawstwie, ale także zachwycała urodą, elegancją, wdziękiem i dowcipem. Zgodziła się, choć łatwo mogła odmówić, nie będąc dialektologiem. Z czasów naszej współpracy zapamiętałam Jej opinię, że gdy dążymy do czegoś, to odsuwamy od siebie inne sprawy. Doradziła mi, żebym nie jechała do Ostrowa Wielkopolskiego na ślub i wesele kuzyna; posłuchałam. Nigdy jednak nie wywierała na mnie presji, nie pytała, ile już napisałam i kiedy skończę.

Inspiracje, które płynęły od promotorki do doktorantki, polegały głównie na wskazywaniu nowych lektur (często w języku angielskim), nowych badaczy, nowych kierunków lingwistycznych. To właśnie prof. Pisarkowa zaproponowała, żebym pierwszą część pracy poświęciła zagadnieniu odczytywania z języka wiadomości o ludziach, którzy ten język stworzyli i go używają.

Przedstawię teraz losy tego rozdziału, który poniekąd zaczął żyć swoim odrębnym życiem. W 1985 r. wzięłam udział w Konferencji Młodych Językoznawców w okolicy Kielc i wygłosiłam referat Przez poznanie języka do poznania człowieka, w którym idee teoretyczne okrasiłam wynikami swoich badań frazeologii gwarowej. Na konferencji zjawił się dziennikarz, mój kolega z czasów studiów, i ogłosił w gazecie „Echo Dnia” wywiad ze mną pod tytułem Przez badanie języka do poznania człowieka (Machnik 1985). W 1987 r. ukazała się moja praca doktorska (Krawczyk-

2 Prof. Lewicki został recenzentem mojej pracy doktorskiej. 
-Tyrpa 1987). Prof. Jerzy Bartmiński (recenzent doktoratu) zaproponował mi publikację rozdziału wstępnego w czasopiśmie „Etnolingwistyka”, co nastąpiło w $1989 \mathrm{r}$. (Krawczyk 1989). Artykuł ten przeczytał moskiewski etnolingwista Nikita Iljicz Tołstoj i umieścił w swoim tekście następujący przypis: „Zob. krótki, ale nasycony faktami przegląd kierunków etnolingwistycznych w artykule Anny Krawczyk" (Tołstoj 1992: 16). Był to dla mnie niesamowity zaszczyt. Również w 1992 r. ukazał się mój artykuł Przez poznanie jezzyka do poznania człowieka (Krawczyk 1992).

Dr hab. Dariusz Bralewski (łódzki romanista) zaproponował mi powtórne wydanie książki w Oficynie Wydawniczej Leksem, co nastąpiło w 2005 r. (Tyrpa 2005).

W roku 2006 moja córka Agnieszka rozpoczęła studia rusycystyczne na Uniwersytecie Jagiellońskim. Zwróciła się do mnie z zapytaniem: „Mamo, czy to ty jesteś tą Anną Krawczyk, której artykuł Język źródłem wiedzy o człowieku poleciła nam prof. Dorota Szumska?".

W 2013 r. brałam udział w konferencji w Wilnie. Tam prof. Kristina Rutkovska powiedziała mi, że prof. Tołstoj tenże artykuł zalecał czytać doktorantom w Instytucie Slawistyki Rosyjskiej Akademii Nauk, a ona do nich należała. Wtedy K. Pisarkowa już nie żyła, ale zdążyłam powiedzieć o tym prof. Waleremu Pisarkowi, wyrażając wdzięczność dla jego żony. Prawdopodobnie opinii prof. Tołstoja zawdzięczam fakt, że w 2019 r. K. Rutkovska poprosiła mnie o recenzję pracy doktorskiej (Girininkaitė 2019) napisanej w Wilnie. Wielkim przeżyciem było dla mnie odczytanie jej w języku angielskim w sali Uniwersytetu Wileńskiego. Tego wszystkiego nie byłoby bez naukowych inspiracji prof. Pisarkowej ${ }^{3}$.

Ze zdziwieniem odczytałam kiedyś przypis w artykule na temat frazeologii słów ręka i Hand niemieckiej badaczki Eugenii Rechtsiegel: „Eine ausgezeichnete Aufarbeitung dieser thematischen Gruppe für die polnischen Dialekte bietet Krawczyk-Tyrpa A., Frazeologia somatyczna w gwarach polskich [...]" (Rechtsiegel 1992: 342). Potem znalazłam informację, że K. Pisarkowa w 1969 r. napisała recenzję książki E. Rechtsiegel (Pisarkowa 1969) ${ }^{4}$. Być może znały się i to moja promotorka przekazała jej informację o Frazeologii somatycznej.

Lata 1988-2003 spędziłam w Bydgoszczy, ale mój kontakt z K. Pisarkową trwał nadal. Pisywałyśmy do siebie. Była też łaskawa opublikować w "Języku Polskim" recenzję mojej pracy habilitacyjnej (Pisarkowa 2002). W 2003 r. wróciłam do Krakowa, gdzie znów się spotykałyśmy. W 2008 r. zaprosiła mnie do redakcji „Języka Polskiego" i powierzyła mi funkcję sekretarza naukowego, którą pełniłam przez dwa lata, nabywając nowych doświadczeń i umiejętności. Jakim promotorem była dla mnie K. Pisarkowa? Hojnym i wiernym do końca.

3 Inspiracje promotorki docenia też inny Jej doktorant: „Chciałbym wyrazić wdzięczność Pani Profesor Krystynie Pisarkowej za zainteresowanie mnie kiriwiną (językiem Wysp Trobrianda) oraz za wieloletnie inspiracje naukowe" (Szczerbowski 2003: 309).

4 O tej recenzji wspomina Stanisław Urbańczyk we wstępie do wyboru prac Krystyny Pisarkowej (Urbańczyk 1994: 7). 


\section{Krystyna Pisarkowa - autorka pewnego artykułu}

W roku akademickim 1970/1971 K. Pisarkowa przeprowadziła ankietę dotyczącą stereotypów narodowych wśród studentów Uniwersytetu Jagiellońskiego i Uniwersytetu Śląskiego. Skonfrontowała wyniki z danymi leksykalnymi i paremiologicznymi. Efekt badań przedstawiła na sesji Instytutu Badań Literackich PAN „Walka z cudzoziemszczyzną w kulturze polskiej (Ksenofobia a postawa otwarta)" w $1971 \mathrm{r}$. $\mathrm{Z}$ powodu sprzeciwu cenzury tekst Jej referatu nie wszedł do tomu pokonferencyjnego Swojskość i cudzoziemszczyzna w dziejach kultury polskiej (Stefanowska 1973; por. Pisarkowa 1976/1994: 220, 233). W roku 1973 niemiecka badaczka Uta Quasthoff opublikowała książkę, której tytuł w przekładzie na język polski brzmi Uprzedzenia społeczne a komunikacja. Analiza językoznawcza stereotypu (Quasthoff 1973). K. Pisarkowa połączyła swój odrzucony przez cenzurę tekst z informacją o pracy U. Quasthoff i tak powstał artykuł Konotacja semantyczna nazw narodowości, opublikowany w 1976 r. w „Zeszytach Prasoznawczych” (Pisarkowa 1976/1994). Maria Peisert zauważyła: „Zapewne np. jakieś pozajęzykowe względy zdecydowały, że w artykule Pisarkowej nie została przedstawiona konotacja semantyczna nazwy Rosjanin, choć - jak wynika z informacji wstępnej - została ona przez nią zbadana" (Peisert 1992: 210). Można się tylko domyślać, że usunięcie fragmentu o stereotypie Rosjanina wpłynęło pozytywnie na decyzję cenzury.

W dalszym ciągu tekstu pragnę przedstawić prace, dla których autorów omawiany tekst stanowił inspirację. To jeden słownik i dwadzieścia trzy monografie. Nie biorę pod uwagę artykułów, bo trudno byłoby je zliczyć.

Dziesięć lat po tym, jak K. Pisarkowa badała stereotypy u studentów, w $1980 \mathrm{r}$. ukazał się Słownik ludowych stereotypów językowych. Zeszyt próbny. Jego pomysłodawca i kierownik naukowy J. Bartmiński pisał w Założeniach teoretycznych słowni$k a$ : „Jak słusznie stwierdza K. Pisarkowa, można przyjąć, że »stereotypy są równoznaczne z konotacją semantyczną nazwy"” (Bartmiński 1980: 13).

Do tego zdania, cytowanego za J. Bartmińskim, nawiązał po 20 latach antropo$\log$ kultury pracujący w Instytucie Sztuki PAN Zbigniew Benedyktowicz w podrozdziale Stereotyp i symbol swojej książki Portrety „obcego”. Od stereotypu do symbolu (Benedyktowicz 2000: 96).

Inny tekst J. Bartmińskiego, Stereotyp jako przedmiot lingwistyki z 1985 r. (Bartmiński 1985), skierował uwagę rusycysty Andrzeja Kępińskiego, autora książki Lach i Moskal. Z dziejów stereotypu, na artykuł K. Pisarkowej. Uczony pisze:

Jak uważa Jerzy Bartmiński, który dokonał przeglądu stanowisk badaczy i analizy zastosowania stereotypu w badaniach językoznawczych, za początek lingwistycznych badań nad stereotypami w Polsce można uznać rozprawy Walerego Pisarka i Krystyny Pisarkowej. Autorka bardzo inspirującej pracy o konotacji semantycznej nazw narodowości traktuje stereotypy jako zjawisko psychologiczne, socjologiczne i z racji obecności w każdym języku - językowe. Istotna dla nas jest teza, iż stereotypy 
funkcjonują w systemie języka jako nadwyżki wartości znaczeniowej nad znaczeniem podstawowym i etnonimy zawierają w swych konotacjach składniki emocjonalnego nacechowania w postaci subiektywnych ocen, uprzedzeń i norm pragmatycznych [...] (Kępiński 1990: 13).

W 1980 r. powstała książka Marii Brzeziny Polszczyzna Niemców (wydana dopiero w 1989 r. (Brzezina 1989)), w której bibliografii, a również w bibliografiach kolejnych monografii tej autorki: Stylizacja rosyjska. Stylizacja jezykowa i inne ewokanty rosyjskości w utworach literackich ukazujących okres zaborów (Brzezina 1997) oraz Kozak ukraiński. Studium językowe (Strycharska-Brzezina 2005) znajdujemy artykuł K. Pisarkowej.

Do omawianego tekstu sięgnął Ryszard Tokarski w swej książce Struktura pola znaczeniowego (studium jezzykoznawcze). Wspomina o nim w podrozdziale Konotacja jako treściowy składnik wyrazu. Pisze o tym, że „potencjalnie tkwiące w jednostce leksykalnej cechy nieistotne, przywoływane w niektórych tylko kontekstach” (Tokarski 1984: 14) są różnie określane przez różnych badaczy, a przez K. Pisarkową - jako stereotyp. Dodaje: „Bardzo bogate konotacje mają, jak wykazała K. Pisarkowa, nazwy narodowości” (ibid.).

W 1987 r. ukazała się rozprawa doktorska Anny Krawczyk-Tyrpy Frazeologia somatyczna w gwarach polskich (Krawczyk-Tyrpa 1987). Rozdział 1.1 zatytułowany Język źródłem wiedzy o człowieku przynosi przegląd prac, w których jest mowa o utrwaleniu w języku kodowanych w nim w ciągu wieków schematów myślenia wspólnoty językowej. Wśród nich jest wymieniony artykuł K. Pisarkowej Konotacja semantyczna nazw narodowości (ibid.: 19-20) ${ }^{5}$. Nie mogło zabraknąć odniesienia do tego tekstu w książce tejże autorki Cudzoziemcy i obce kraje $w$ dialektach polskich:

Krystyna Pisarkowa w swoim pionierskim artykule zastosowała dwie metody: analizę utrwalonych w języku i zapisanych w słownikach leksemów i frazemów oraz ankiety, które weryfikują znajomość tych jednostek u współczesnych Polaków, ewentualnie wzbogacają stare stereotypy o nowe elementy. Kontynuatorzy badań tej uczonej także często stosowali ankietowanie (Tyrpa 2011: 15).

Artykuł, o którym mowa, znalazł się w bibliografii dwóch monografii z zakresu aksjolingwistyki z 1992 r. Są to: Język wartości Jadwigi Puzyniny (Puzynina 1992) i Wartościowanie w języku potocznym Elżbiety Laskowskiej (Laskowska 1992).

W 1994 r. ukazała się monografia rusycysty T. Szczerbowskiego O grach językowych $w$ tekstach polskiego i rosyjskiego kabaretu lat osiemdziesiątych, w której wstępie czytamy: „Z wdzięcznością przyjąłem nieocenioną pomoc promotora, Pani Prof. Dr hab. Krystyny Pisarkowej” (Szczerbowski 1994: 5), a rozdział 5 Stereotypy etniczne jako element „wspólnego świata” obfituje w odesłania tekstów kabaretowych

5 Zgodnie z tym, co powiedziano w części 1. niniejszego tekstu, uwagi o artykule K. Pisarkowej powtórzono w: Krawczyk 1989: 35, 1992: 81 i Tyrpa 2005: 24-24. 
do fragmentów artykułu promotorki na temat stereotypów Żyda, Cygana, Niemca, Amerykanina i Murzyna. Artykuł K. Pisarkowej znalazł się również w bibliografii kolejnej książki T. Szczerbowskiego Gry językowe w przekładach „Ulissesa” Jamesa Joyce’a (Szczerbowski 1998).

Aleksandra Niewiara poświęciła problematyce stereotypów narodowych aż pięć swoich książek. W pierwszej z nich - Wyobrażenia o narodach $w$ pamiętnikach $i$ dziennikach $z$ XVI-XIX wieku - kilkukrotnie powołuje się na tekst K. Pisarkowej, wspominając o tym, że uczona posłużyła się metodą ankietową (na wzór socjologów) (Niewiara 2000: 9), że uważała słowo za bodziec do uruchomienia stereotypu (ibid.: 10), że skłaniała się do poglądu, iż nazwy własne oprócz referencji mają też charakterystyki stereotypowe (ibid.: 15), oraz twierdziła, że:

Po pierwsze - apelatywa z czasem stają się li tylko nazwami pospolitymi nie kojarzonymi już bezpośrednio z nazwą narodowości, po drugie - pewne stereotypowe cechy, kiedyś silnie zakorzenione w świadomości, z czasem ustępują. Niektóre apelatywa stają się wtedy niemotywowane (ibid.: 22).

W książce Imagologia. Pamięć zbiorowa, umyst i kultura z 2019 r. Niewiara wymienia tych, którzy zajmują się stereotypami: filozofów, socjologów, literaturoznawców, psychologów, kulturoznawców, a wśród językoznawców właśnie K. Pisarkową (Niewiara 2019: 9). W kolejnych trzech monografiach: Moskwicin - Moskal - Rosjanin $w$ dokumentach prywatnych. Portret (Niewiara 2006), Ksztalty polskiej tożsamości. Potoczny dyskurs narodowy w perspektywie etnolingwistycznej (XVI-XX w.) (Niewiara 2009) i My i Inni - ewolucja wyobrażeń. Polski dyskurs prasowy w świetle imagologii i pamięci zbiorowej (Niewiara 2020) w bibliografiach nie zabrakło artykułu o konotacji semantycznej nazw narodowości.

Artykuł ten stał się też inspiracją dla socjologa Zbigniewa Bokszańskiego, który w książce Stereotypy a kultura snuł rozważania:

Ciągle zdaje się natomiast powracać kwestia hybrydalnego charakteru koncepcji stereotypu. Hybrydalność owa wydaje się polegać głównie na prezentowanej wyżej niejednoznacznej przynależności ontologicznej stereotypu. Pisarkowa za Quasthoff pyta: „Czy stereotyp należy do parole czy do langue?”. Pytanie to pojawia się wprawdzie w kontekście psycho- i socjolingwistycznego podejścia do badań stereotypów, ale jak się wydaje, nic nie stoi na przeszkodzie temu, aby opozycję de Saussure’a potraktować jako ogólniejsze, nie tylko językoznawcze rozróżnienie. W takiej właśnie postaci widać, co podkreśla U. Quastoff, że stereotyp jako całość nie daje się bez reszty przypisać kategorii langue (Bokszański 2001: 31).

Nie pominęła artykułu K. Pisarkowej Dorota Brzozowska, autorka książki Polski dowcip etniczny. Stereotyp a tożsamość. Wymieniła go, omawiając stan badań nad stereotypami i humorem (Brzozowska 2008: 35).

Znalazł się on w bibliografii monografii Beaty Ziajki Językowo-kulturowy obraz świata społeczności wiejskiej utrwalony w przezwiskach i przydomkach (na przykła- 
dzie nieoficjalnych antroponimów mieszkańców Zagórza i wsi okolicznych w powiecie chrzanowskim) z 2014 r. (Ziajka 2014).

W tym samym roku ukazała się praca Mirosławy Sagan-Bielawy Dziedzictwo pozaborowe. Społeczna świadomość językowa Polaków w Drugiej Rzeczypospolitej. W podrozdziale Funkcja stereotypu w świadomości społecznej autorka przypomina interdyscyplinarność tego pojęcia sformułowaną przez K. Pisarkową i to, że omówiła Ona bogatą literaturę przedmiotu (Sagan-Bielawa 2014: 56). W podrozdziale o nazwach własnych pisze:

K. Pisarkowa analizowała znaczenia przenośne, związki frazeologiczne, derywaty słowotwórcze, przysłowia, synonimiczne nazwy przezwiskowe, przyporządkowanie epitetów nazwom narodowości. Stereotyp definiowała jako nadwyżkę wartości znaczeniowej nazwy własnej nad znaczeniem prymarnym (ibid.: 60).

Wreszcie ustalenia K. Pisarkowej pomogły badaczce polszczyzny w Polsce zjednoczonej po zaborach odnieść się do określeń typu Galicjak, Galicjanin:

Nawiązując do badań konotacji semantycznej nazw narodowości, możemy stwierdzić, że Galicjok i jemu podobne przezwiska stały się przykładami „nazw niemal pospolitych", jak określa je Krystyna Pisarkowa [...], apelatywów, których konotacja semantyczna stanowi stereotyp grupy, w tym wypadku grupy regionalnej (ibid.: 97-98).

W powyższym przeglądzie starałam się ukazać oddziaływanie jednego tekstu K. Pisarkowej na czternaścioro autorów. Przeważają wśród nich językoznawcy poloniści, ale są też dwaj rusycyści, antropolog kultury i socjolog. Omówione książki ukazały się w latach 1980-2020, czyli w ciągu czterdziestu lat. Pięć z nich powstało w czasie, gdy pani profesor już nie było między nami. Dlatego w tytule mego wystąpienia użyłam określenia „ta, która inspiruje” w czasie teraźniejszym, bo inspiracja trwa i będzie nadal trwała dzięki pozostawionym przez uczoną dziełom ${ }^{6}$.

\section{Suplement}

W latach 1974-1975 mój kuzyn Andrzej Ponikowski przebywał w Londynie. Mieszkał jako wolontariusz w domu katolickim w dzielnicy Ealing, przy ulicy Queen’s

6 Pisała o tym Krystyna Kowalik: „Z całą pewnością Jej publikacje mają wyjątkowy walor poznawczy, odkrywając mało znane postaci, obszary i mechanizmy funkcjonowania języka. W stylu nie do podrobienia teksty te zawierają wiele teoretycznych uogólnień, wskazówek metodologicznych i przemyśleń filozoficznych. To Jej osobisty wkład w dorobek polskiego językoznawstwa i inspiracja dla przyszłych badaczy" (Kowalik 2010: 13).

7 Wnuk Antoniego Ponikowskiego, premiera Polski (1918, 1921-1922), ministra wyznań religijnych i oświecenia publicznego oraz kultury i sztuki (1917-1918, 1921-1922) i rektora Politechniki Warszawskiej (1921-1922, 1923-1924 oraz pełniącego obowiązki rektora w 1945 r.). 
Walk, gdzie opiekowano się ludźmi ciężko chorymi. Dom będący pod zarządem zakonu serwitów ${ }^{8}$ istniał od lat 60. do lat 90. XX w. Instytucja ta funkcjonowała częściowo dzięki dobroczynności. Pewnego razu kuzyn został poproszony o przywiezienie zbioru książek od pewnego ofiarodawcy mieszkającego na obrzeżach Londynu. Książki były przeznaczone do wyprzedaży, a zysk miał zasilić fundusz domu opieki. Ponieważ mój kuzyn był anglistą językoznawcą (magisterium zdobył na seminarium prof. Jana Rusieckiego), odkupił te książki, które uznał za przydatne dla siebie. Wśród nich znalazł się egzemplarz dzieła Charlesa K. Ogdena i Ivora A. Richardsa The Meaning of Meaning z $1930 \mathrm{r}$. z suplementem autorstwa Bronisława Malinowskiego - The Problem of Meaning in Primitive Languages (Ogden, Richards 1930). W 1981 r. A. Ponikowski wstąpił do zakonu dominikanów, a zgromadzone lektury lingwistyczne ofiarował mnie. Ja z kolei, wiedząc o tym, że prof. K. Pisarkowa zajmuje się Malinowskim - udostępniłam Jej tę książkę, a dzięki temu znalazłam się w gronie osób, którym dziękowała:

Dziękuję [...] prof. dr Annie Krawczyk-Tyrpie, słuchaczce moich najwcześniejszych wykładów o językoznawstwie „Bronia”, której zawdzięczam magiczny antykwaryczny londyński - upstrzony niezliczoną ilością rękopiśmiennych uzupełnień, może Austina, a może nawet samego Wittgensteina - egzemplarz książki Richardsa i Ogdena z Suplementem Malinowskiego (Pisarkowa 2000: 5).

Rzeczywiście, ten egzemplarz jest pokryty licznymi podkreśleniami, uwagami na marginesach, przyklejonymi kółeczkami, a wszystko w wielu kolorach. Są to plastyczne dowody niezwykle intensywnej lektury. Fotografię jednej strony dzieła umieściła K. Pisarkowa w swojej monografii Językoznawstwo Bronisława Malinowskiego, opatrując ją podpisem „Antykwaryczny egzemplarz The Meaning of Meaning z barwnymi notatkami nieznanego właściciela" (ibid.: 155). Udostępniając tę książkę, mogłam się choć odrobinę zrewanżować prof. Pisarkowej za wszelkie dobro, którego od Niej doświadczyłam.

\section{Literatura}

BARTMiński J., 1980, Założenia teoretyczne słownika, [w:] J. Adamowski i in. (red.), Słownik ludowych stereotypów językowych. Zeszyt próbny, „Studia i Materiały - Centrum Informacji Naukowej Problemu Węzłowego 11.1", Wrocław, s. 7-36.

BARTMiński J., 1985, Stereotyp jako przedmiot lingwistyki, [w:] M. Basaj, D. Rytel (red.), Z problemów frazeologii polskiej i słowiańskiej, Wrocław, t. 3, s. 25-53.

Benedy ktowicz Z., 200o, Portrety „obcego”. Od stereotypu do symbolu, Kraków.

8 Zakon serwitów o pełnej nazwie Słudzy Najświętszej Maryi Panny (łac. Ordo Servorum Mariae, OSM) powstał we Florencji w $1233 \mathrm{r}$. Miał siedmiu założycieli, którzy zostali kanonizowani. W Polsce nieobecny. 
Bokszański Z., 2001, Stereotypy a kultura, wyd. 2, „Monografie Fundacji na rzecz Nauki Polskiej. Seria Humanistyczna”, Wrocław.

Brzezina M., 1989, Polszczyzna Niemców, „Języki Mniejszości Narodowych w Tekstach Literackich i Folklorystycznych", Warszawa - Kraków.

Brzezina M., 1997, Stylizacja rosyjska. Stylizacja językowa i inne ewokanty rosyjskości w utworach literackich ukazujących okres zaborów, Warszawa.

Brzozowska D., 2008, Polski dowcip etniczny. Stereotyp a tożsamość, „Studia i Monografie - Uniwersytet Opolski”, nr 399, Opole.

Girininkaité V., 2019, Kalbų ir kultūru sąveika keliakalbio idiolekte. Atvejo analizé: Vytauto Civinskio Dienoraštis (1904-1910): disertacija / Interaction of the Languages and Cultures in the Idiolect of a Multilingual. Case Study: The Diary (1904-1910) of Vytautas Civinskis (Witold Cywiński), rozprawa doktorska, mszps.

Karpluk M., 2010, Profesor Krystyna Pisarkowa (30 I 1932 - 27 II 2010), „Język Polski” XC, S. $161-166$.

KĘPIŃsKi A., 1990, Lach i Moskal. Z dziejów stereotypu, Warszawa - Kraków.

Kowalik K., 2010, Profesor Krystyna Pisarkowa (30 I 1932 - 27 II 2010), „LingVaria” nr 2 (10), S. 7-14.

KRAwCzyк A., 1989, Język źródłem wiedzy o człowieku, „Etnolingwistyka. Problemy Języka i Kultury" 2, s. 29-38.

Krawczyк A., 1992, Przez poznanie języka do poznania człowieka, [w:] M. Preyzner (red.), Języ, teoria - dydaktyka. Materiały X Konferencji Młodych Językoznawców-Dydaktyków, Kielce 1992, Kielce, s. 79-85.

KraWCZyK-Tyrpa A., 1987, Frazeologia somatyczna $w$ gwarach polskich. Związki frazeologiczne o znaczeniach motywowanych cechami części ciała, „Prace Instytutu Języka Polskiego", nr 53, Wrocław.

Laskowska E., 1992, Wartościowanie w języku potocznym, Bydgoszcz.

Mаснniк J., 1985, Przez poznanie języka do poznania człowieka, rozmowa $z$ dr Anna Krawczyk z Zakładu Dialektologii Instytutu Języka Polskiego PAN w Krakowie, „Echo Dnia” 17-19 V, s. 3.

NiewIARA A., 2000, Wyobrażenia o narodach w pamiętnikach i dziennikach z XVI-XIX wie$k u$, „Prace Naukowe Uniwersytetu Śląskiego w Katowicach”, nr 1849, Katowice.

Niewiara A., 2006, Moskwicin - Moskal - Rosjanin w dokumentach prywatnych. Portret, Łódź.

Niewiara A., 2009, Kształty polskiej tożsamości. Potoczny dyskurs narodowy w perspektywie etnolingwistycznej (XVI-XX w.), „Prace Naukowe Uniwersytetu Śląskiego w Katowicach", nr 2708, Katowice.

Niewiara A., 2019, Imagologia. Pamięć zbiorowa, umyst i kultura, „Prace Naukowe Uniwersytetu Śląskiego w Katowicach", nr 3842, Katowice.

Niewiara A., 2020, My i Inni - ewolucja wyobrażeń. Polski dyskurs prasowy w świetle imagologii i pamięci zbiorowej, „Prace Naukowe Uniwersytetu Śląskiego w Katowicach”, nr 3941, Katowice.

Ogden C.K., Richards I.A., 1930, The Meaning of Meaning. A Study of the Influence of Language upon Thought and of the Science of Symbolism with Supplementary Essays by B. Malinowski and F.G. Crookshank, London.

Peisert M., 1992, Nazwy narodowości i ras we współczesnej polszczyźnie potocznej, [w:] J. Anusiewicz, F. Nieckula (red.), Język a kultura, t. 5: Potoczność w języku i w kulturze, Wrocław, s. 209-223. 
Pisarkowa K., 1969, [rec.] E. Rechtsiegel, Die poetischen Funktionen der Wortverbindung in der Sprache Władysław Broniewskis. Abhandlungen der Deutschen Akademie der Wissenschaften zu Berlin, Klasse für Sprache, Literatur u. Kunst. Jahrgang $1968 \mathrm{Nr}$ 4, Akademie-Verlag. Berlin 1968, s. 58, „Język Polski” XLIX, s. 228-231.

PIsarkowa K., 1976/1994, Konotacja semantyczna nazw narodowości, „Zeszyty Prasoznawcze" nr 1, s. 5-26; przedruk w: eadem, Z pragmatycznej stylistyki, semantyki i historii języka. Wybór zagadnień, „Prace Instytutu Języka Polskiego”, nr 89, Kraków 1994, s. 215-234.

PISARKowa K., 2000, Językoznawstwo Bronisława Malinowskiego, t. 1: Więzy wspólnego ję$z y k a$, Kraków.

Pisarkowa K., 2002, [rec.] Anna Krawczyk-Tyrpa, Tabu w dialektach polskich, Wydawnictwo Akademii Bydgoskiej im. Kazimierza Wielkiego, Bydgoszcz 2001, s. 345, „Język Polski” LXXXII, s. 367-369.

PuZYNINA J., 1992, Język wartości, Warszawa.

Quasthoff U., 1973, Soziales Vorurteil und Kommunikation. Eine sprachwissenschaftliche Analyse des Stereotyps, Frankfurt am Main.

Rechtsiegel E., 1992, Zur mit dem lexem ręka - Hand gebildeten Phraseologie des polnischen und deutschen, „Prace Filologiczne” XXXVII, s. 341-348.

Sagan-Bielawa M., 2014, Dziedzictwo pozaborowe. Społeczna świadomość językowa Polaków w Drugiej Rzeczypospolitej, „Biblioteka LingVariów”, t. 18, Kraków.

Stefanowska Z. (red.), 1973, Swojskość i cudzoziemszczyzna w dziejach kultury polskiej, Warszawa.

Strycharska-Brzezina M., 2005, Kozak ukraiński. Studium językowe, Kraków.

SzCZERbowski T., 1994, O grach językowych $w$ tekstach polskiego i rosyjskiego kabaretu lat osiemdziesiątych, „Prace Instytutu Języka Polskiego”, nr 92, Kraków.

Szczerbowski T., 1998, Gry językowe w przekładach „Ulissesa” Jamesa Joyce’a, „Prace Instytutu Języka Polskiego", nr 105, Kraków.

SzczerbowsKi T., 2003, Wszystko ma swój czas w przekładzie na język Kiriwiny, [w:] I. Bobrowski (red.), Anabasis. Prace ofiarowane Profesor Krystynie Pisarkowej, Kraków, s. 309-316.

TokARski R., 1984, Struktura pola znaczeniowego (studium językoznawcze), „Prace Wydziału Humanistycznego - Lubelskie Towarzystwo Naukowe. Monografie”, t. 17, Warszawa.

To£STOJ N.I., 1992, Język a kultura (niektóre zagadnienia słowiańskiej etnolingwistyki), „Etnolingwistyka. Problemy Języka i Kultury” 5, s. 15-25.

Tyrpa A., 2005, Frazeologia somatyczna. Związki frazeologiczne o znaczeniach motywowanych cechami części ciała w gwarach polskich, wyd. 2, Łask.

TyrPA A., 2011, Cudzoziemcy i obce kraje w dialektach polskich, Kraków.

Urbańczy K S., 1994, Profesor Krystyna Pisarkowa w roli jubilata, [w:] K. Pisarkowa, Z pragmatycznej stylistyki, semantyki i historii języka. Wybór zagadnień, „Prace Instytutu Języka Polskiego", nr 89, Kraków, s. 5-8.

ZIAJKA B., 2014, Językowo-kulturowy obraz świata społeczności wiejskiej utrwalony w przezwiskach i przydomkach (na przykładzie nieoficjalnych antroponimów mieszkańców Zagórza i wsi okolicznych w powiecie chrzanowskim), Kraków. 


\section{Krystyna Pisarkowa - The One Who Inspires}

Abstract

The article consists of three parts. In the first one: Krystyna Pisarkowa as a Supervisor, the author shares her memories from the times when she wrote the doctoral thesis supervised by Pisarkowa.

In the second part: Krystyna Pisarkowa - the Author of an Article, the author discusses how the text by Pisarkowa entitled Semantic Connotation of Nationalities provided inspiration to fourteen authors of twenty-three monographs and one lexicon. Most of those scholars are experts in Polish language and linguists, but the thoughts included in Pisarkowa's article also influenced two experts in Russian studies: one sociologist and one anthropologist of culture.

Those books were published within 40 years $(1980-2020)$. Five of them were published after the death of Krystyna Pisarkowa. This proves the power of her article's influence.

The third part of the article is entitled Supplement. It describes the history of the book by Ogden and Richards: The Meaning of Meaning. A Study of The Influence of Language upon Thought and of The Science of Symbolism with Supplementary Essays by B. Malinowski and F. G. Crookshank, which followed a strange route from London and reached Pisarkowa who used it while writing: Linguistics by Bronisław Malinowski, vol. 1: Bonds of Shared Language (2000). 